Марина РУДІНА, кандидат педагогічних наук, дочент, дочент кафедри англійської філології і перекладу Навчально-наукового гуманітарного інституту Національного авіаційного університету (Київ, Україна)rudinamv@gmail.com

\title{
НАУКОВО-ТЕОРЕТИЧНИЙ І МЕТОДИЧНИЙ АСПЕКТИ ФОРМУВАННЯ ПЕРЕКЛАДАЦЬКОЇ КОМПЕТЕНТНОСТІ СТУДЕНТІВ
}

Розглянуто науково-теоретичний $i$ методичний аспекти формування перекладацької компетентності студентів як майбутніх фахівців; звернено увагу на широке коло досліджень проблеми науковиями; відзначено розмаїття поглядів на методичний аспект, використання інформачійних технологій $i$ методик, особистісну мотивацію студентів; показано, що методичний аспект корегується стрімким розвитком технологій, інноваційними методиками, особистісним фактором, самостійними доступом студентів до знань, потребами замовників перекладаџьких послуг; усталені науково-теоретичні засади становлять підгрунтя процесу навчання студентів.

Ключові слова: перекладацька компетентність; методичний аспект; тренди в освіті студентів; інноваційні освітні технології; стандарти професії перекладача.

Marina RUDINA,

PhD in Pedagogic Science, Associate professor, Associate Professor of English Philology and Translation Department Humanitarian Institute National Aviation University (Kyiv,Ukraine)rudinamv@gmail.com 


\section{SCIENTIFIC-THEORETICAL AND METHODOLOGICAL ASPECTS OF FORMATION OF TRANSLATION COMPETENCE OF THE STUDENTS}

The article shows scientific-theoretical and methodological aspects of the formation of translation competence of the students of philology as the future specialists, an attention is paid to a wide range of domestic and foreign approaches, it is investigated a wide range of modern viewpoints to the methodological aspect and the usage of modern information technologies and methods which facilitate personal students' motivation to acquire translation as the greatest demand on the labour market.

Ukrainian students focus on the most common challenges arising in the process of learning English for the future professional activity. They need to achieve general competences. The most important of them is communicative language competence, which includes such components as linguistic component - lexical, phonological, syntactical knowledge and skills, sociolinguistic component, pragmatic component knowledge, existential competence and skills and know- how relating to linguistic system and its sociolinguistic variation. These statements argument the importance of foreign communicative competence. It is important for student to get the knowledge in sense of self-actualization, the ability of self-reflection while studying. Critical thinking is also important. It allows evaluating and correcting the studying process; interpretative culture helps to find and show your own thoughts and get an ability to study in a system of intersubjective relations. Learning foreign languages is a personal necessity. Successful foreign communication is not only a desire to contact but also the ability to communicate successfully, especially in professional discourse.

Scientific-theoretical aspect is the basis of methodological approaches to the formation of translation competence of the students of philology as the future specialists. Methodological aspect is corrected by the fast development of information technologies, innovative methods, wide students' self-access to knowledge and needs of the customer of the translation service. A wide range of the scientific viewpoints to the development of modern technologies and methodologies and their results can be proved or disapproved over time. 
Key words: translation competence; methodological aspect; trends in students' education; innovative educational technologies; standards of translation profession.

\title{
Марина РУДИНА,
} кандидат педагогических наук, доиент, доцент кафедры английской филологии и перевода Учебно-научного гуманитарного института Национального авиационного университета (Киев, Украина) rudinamv@gmail.com

\section{НАУЧНО-ТЕОРЕТИЧЕСКИЙ И МЕТОДИЧЕСКИЙ АСПЕКТЫ ФОРМИРОВАНИЯ ПЕРЕВОДЧЕСКОЙ КОМПЕТЕНТНОСТИ СТУДЕНТОВ}

\begin{abstract}
Рассмотрень научно-теоретический $u$ методический аспекть формирования переводческой компетентности студентов как будущих специалистов; акцентировано внимание на широком круге исследований проблемы учеными; отмечено разнообразие взглядов на методический аспект, использование информационных технологий и методик, личностную мотивацию студентов; показано, что методический аспект корректируется стремительным развитием информационных технологий, инновационными методиками, личностным фактором, широким доступом студентов $к$
\end{abstract} знаниям, требованиями заказчиков услуг перевода; устоявшиеся научнотеоретические основы являются фундаментом процесса обучения студентов.

Ключевые слова: переводческая компетентность; методический аспект; тренды в образовании студентов; инновачионные образовательные технологии; стандарты профессии переводчика.

Постановка проблеми. Інтеграція світового ринку праці, глобалізація цивілізаційного розвитку інтенсифікують життя людей, породжують нові професійні цінності. Професійний іншомовний дискурс і нові явища в освіті 
впливають на професійну діяльність викладача іноземної мови вищого навчального закладу, який інтегрує традиційні науково-теоретичні підходи до формування перекладацької компетентності студентів і можливості сучасних методик, досягнення вітчизняної науки, світовий педагогічний досвід, інформаційні технології навчального призначення тощо. Уміння перекладу в межах професії підвищують конкурентоздатність фахівців, чим визначається актуальність i практична значимість інноваційних методик і технологій формування перекладацької компетентності студентів. Сучасний професійний педагогічний дискурс в основному забезпечує вирішення багатьох освітніх проблем, розвиває науково-теоретичний i методичний аспекти формування перекладацької компетентності студентів, проте проблема потребує вивчення.

Аналіз досліджень і публікацій. Інтенсивність розвитку в ХХІ ст. світової педагогічної думки зросла завдяки трансформації професійних знань на основі перекладу фахових текстів. Доступність надбань світової спільноти дозволяє орієнтуватися в інноваційних напрямах i технологіях навчання студентів 3 метою формування перекладацької компетентності як інтегрованої якості й підгрунтя майбутньої професійної діяльності. Так, автори «Тhe Open Book of Social Innovation» акцентують увагу на соціальному характері інноваційного розвитку освіти [22]; «Тренди освітніх технологій 2015 року» [13] орієнтують на потребу незалежності від «чужого» перекладу в професійній діяльності; «Тренди в освіті 2017 року» [12] презентують широкий арсенал інноваційних освітніх технологій: Мобільна освіта (Mobile Learning), Навчання на базі даних у хмарі (Cloud-Based Learning), Розширена реальність (Augmented Reality), Навчання на базі відкритих освітніх pecypciв (Open Source Learning), Індивідуальне середовище навчання (Personal Learning Environment), MOOC (Massive Open Online Courses), Навчання, зорієнтоване на учня (Student-Centred Learning), Віртуальний асистент (Virtual Learning Assistant), Комплементарне навчання (Blended Learning - B-Learning) тощо.

Мета статті - огляд сучасних науково-теоретичних і методичних аспектів формування перекладацької компетентності студентів. 
Виклад основного матеріалу. Концептуальні засади розуміння сутності перекладацької компетентності та фундаментальні основи теорії перекладу в процесі загальнонаукового розвитку не втратили своєї актуальності. Теорії закономірних відповідностей Я. Рецкера і рівнів еквівалентності В. Комісарова, концепції динамічної еквівалентності Ю. Найди і мовних значень і черговості їх відтворення в перекладі Л. Бархударова залишаються ядром формування перекладацької компетентності студентів.

Аналіз науково-філологічних джерел показує, що компетентність (competence) набула концептуального значення i в загальній теорії професіоналізму. Н. Хомський, уперше використавши цей термін у теорії генеративної граматики, пов'язав його зі здатністю носія мови володіти системою мови. Компетентність, на його думку, не природжена здатність, а властивість, що формується в результаті взаємодії індивіда із соціальним середовищем, а набуття competence передбачає соціальний досвід індивіда [14]. Етнолінгвіст Д. Хаймс вважав комунікативною компетентністю здатність особистості бути учасником мовленнєвої діяльності, представив ії як навички й уміння адекватно використовувати мову в конкретній ситуації спілкування [19]. Дж. Р Серль визнав набуття комунікативної компетентності найважливішою метою процесу навчання [20]. Отже, перекладацька і комунікативна компетентності діалогічно пов'язані, формуються в процесі навчання студентів, удосконалюються в професійній діяльності перекладача.

Ми виходимо з того, що перекладацька компетентність є комплексним інтелектуально-психологічним утворенням особистості, що акумулює здатність фахівця до ефективного спілкування в різних сферах життєдіяльності, знання мовних і мовленнєвих норм, культурних особливостей, уміння використовувати ці знання відповідно до ситуації спілкування іноземною мовою. Перекладацька компетентність $є$ ресурсом створення іншомовних текстів відповідно до поставленої чи зумовленої комунікативної задачі, інтегрує ситуацію спілкування й комунікативний намір. Перекладацька компетентність має забезпечувати професійний успіх фахівця-перекладача [17]. 
Вітчизняні дослідники ведуть активний науковий пошук: теоретичні моделі перекладацької компетентності обгрунтовано Р. Поворознюк [6]; О. Чередниченко визначає складові професійної компетентності перекладача [15]; О. Селіванова кваліфікує процес перекладу як подвійний інтерпретаційно породжувальний дискурс [10]; М. Раренко в Термінологічному словникудовіднику подає поняття перекладознавства [11]; іншомовний дискурс, його складові, проблеми вивчення і навчання висвітлено в колективній науковій праці кафедри перекладу ДНУ імені Олеся Гончара [3].

Латишев Л. концептуальну складову перекладацької компетентності трактує як сукупність знань і уявлень перекладача про: сутність перекладу, специфіку, що відрізняє переклад від інших видів мовленнєвого посередництва; загальну мету перекладу та іiі варіанти залежно від тематики і стилістичного жанру тексту; задачі, які вирішує перекладач для досягнення мети; характерні для перекладу колізії цих задач (протиріччя між декількома «потрібно») й основні принципи їх подолання. Ця концептуальна складова для перекладача як музикальний слух для співака: неадекватне уявлення про сутність перекладу призводить до «фальшивих нот»: буквалізмів, вільностей, втрати найважливіших функціонально-комунікативних i когнітивних характеристик вихідного тексту в результаті хибних переваг у процесі їх відтворення, порушення межі припустимого в перекладі, що робить переклад переказом [4]. Концептуальна складова (модель перекладу) має бути технологічною: подавати процес відтворення вихідного тексту розмежованим на аспекти й окремі дії, як процес з певною структурою загальних і часткових задач, що розв'язуються за допомогою визначеного набору засобів і прийомів. Зазначене важливе для аналізу ефективності сучасних науково-теоретичних і методичних аспектів формування перекладацької компетентності студентів.

Науковці вважають, і ми поділяємо їхню точку зору, що на часі виявлення типів перекладацьких стратегій і чинників, які гармонізують перекладацьку компетенцію студента-білінгва (Ж. Горіна); що сучасна методика навчання іноземних мов має звертатися до вербальних і невербальних засобів комунікації 
як культурного прояву поведінки людини; що комунікацію, мову та культуру не можна розділяти в навчальному процесі (В. Коновалова, В. Мирошниченко), що інтегративна сутність поняття перекладацької компетентності зумовлює іï комплексні наукові дослідження: як феномена, як підгрунтя іншомовного дискурсу, як основи крос-культурної комунікації, як засобу компаративістики.

Традиційне тлумачення перекладу трансформується як $\mathrm{i}$ розуміння перекладацької компетентності, а феномен перекладу постає універсальним засобом творення професійного дискурсу в багатовимірному просторі науки.

Методичний аспект формування перекладацької компетентності студентів, на нашу думку, визначається тим, що: вивчення мови - i рідної, і іноземної особистісна потреба; успішність спілкування іноземною мовою забезпечується i бажанням установити контакт, i умінням реалізувати мовний намір у конкретних ситуаціях; уміння перекладу - підгрунтя ефективної професійної діяльності; навчання студентів має бути сучасним - на основі інноваційних i цифрових технологій; педагог має враховувати вимоги ринку праці до фахівцівперекладачів; професійна компетентність викладача має вдосконалюватися.

Особистісна потреба вивчення іноземної мови актуалізується для студента тим, що основний ресурс професії перекладача становлять: базова іноземна мова (декілька мов) - професійна лексика - професійні тексти - професійне спілкування - професійний дискурс - успіх у професії. Значення відповідального ставлення до формування перекладацької компетентності студенти іноді не розуміють, адже легкодоступність інформації (і перекладу) на Інтернет-ресурсах дозволяє перекладати будь-які тексти без особливих зусиль. Означене протиріччя зумовлює науково-методичну проблему: мотивування студентів за допомогою важливих для молоді аргументів, цікавих форм проведення занять. Які аргументи можна вважати переконливими для молоді? Напевне, це відповідність навчальних занять з перекладу потребам практики та ринку праці. D. Kiraly з цього приводу зазначає, що викладання перекладу має грунтуватися на практиці, на тому, чим займаються професійні перекладачі в реальному житті [21]. Вважаємо доцільним використання документів Асоціації 
перекладачів України [2], у яких представлено стандарти професії, причому окремо для письмового та усного перекладу, визначено показники якості для кожного 3 видів. Чітко визначені й кваліфікаційні вимоги до перекладача, охарактеризована його компетентність: він повинен мати базову або повну вищу освіту зі спеціальності; має бути компетентним у мовах, які використовує під час перекладу (професійно володіти мовою початкового тексту і мовою перекладу); має володіти спеціалізацією діяльності замовника перекладу; термінологією тематики (мовами перекладу); бути обізнаним із галузевими міжнародними і національними стандартами; знати і застосовувати міжнародні й національні стандарти в галузі перекладу, що діють на території України. Ці матеріали на заняттях з перекладу ефективні, оскільки показують студентам реальні вимоги ринку праці до майбутньої професії й аргументацію їі оплати.

У стандартах професії (для письмового і усного перекладу) підкреслено важливість дотримання термінології. Відповідно, на заняттях цей аспект вивчення лексики набуває особливого сенсу. Цікавим є підхід C. Durieux. Зазначено, що викладач не повинен ставати «ходячою енциклопедією» відповідних термінів, а має пояснити, як розв'язати проблему 3 термінами: конкретна задача - приклад застосування необхідної стратегії, а саме: а) якщо студент опанував еквівалент терміну, що й буває в більшості ситуацій, це краще, ніж нічого, але викладач повідомив інформацію, яку можна знайти й у словнику; б) якщо студент усвідомив, що в даному контексті дане слово має дане значення і даний еквівалент, то це початок термінологічної картотеки, що більш корисне, проте все ж залишається в рамках фактів - викладач передав корисні знання, але це тільки знання; в) якщо студент опанував механізм пошуку інформації і може його застосувати при роботі з будь-якими термінами за будь-яких обставин, оскільки йдеться про принцип засвоєння незалежно від конкретної ситуації, то це значний крок до опанування стратегій, необхідних для професії перекладача [18]. Отже, викладач сформував уміння, що і є метою. Пропозиції C. Durieux вважаємо актуальним методичним підгрунтям формування перекладацької компетентності студентів. 
Окремі аспекти формування перекладацької компетентності студентів розглянуто нами в попередніх публікаціях $[7 ; 8]$. Зауважимо, що науковотеоретичний аспект цієї проблеми достатньо розроблений, методичний же має широке розмаїття підходів і трактувань, як інноваційно продуктивних, так i дещо суперечливих, у комплексі вони не набули ще стану цілісної теорії.

На методичний аспект впливають такі явища: персоналізація навчання наявність комп’ютерного персонального вікна здобуття інформації за профілем студента; педагогічна інверсія з протиріччям: той, хто вчиться, перевершує знаннями і вміннями педагогів, що $є$ ознакою префігуративної культури інформаційного суспільства, коли дорослі вчаться у дітей (Mead). Сучасні дидактичні моделі потребують викладача, який $є$ не каналом трансляції знань, а творцем освітнього простору в багатовимірній ролі: тьютор (tutor), коуч (coach), експерт (expert). Освітні портали, You Tube, VOD, блоги й інші відкриті ресурси змінили якість доступу до знань, зміст методик навчання перекладачів.

Науковці вивчають і «вузькі» методичні проблеми: багаторівневий опис комунікативної компетентності як підгрунтя перекладацької [9]; перекладацькі помилки як дидактичний матеріал [1]; протиріччя методик навчання перекладу й практичного курсу іноземної мови: перекладацькі трансформації, що через невизначеність їх природи в семантичній теорії перекладу зумовлюють втрату технології перекладу [16]; психолого-педагогічні особливості професійної компетентності майбутніх перекладачів [5]; підвищення ефективності занять методом вирішення типових перекладацьких проблем [4] тощо.

Висновки. Аналіз доводить, що науково-теоретичні засади традиційних i інноваційних методик формування перекладацької компетентності студентів залишаються важливим об'єктом сучасної педагогічної науки, розвиваються на основі вітчизняного й зарубіжного досвіду. Методичний аспект активно досліджується і створюється науковцями, корегується стрімким розвитком інформаційних технологій, інноваційними методиками, особистісним фактором i самостійним доступом студентів до знань, потребами замовників послуг перекладу на сучасному світовому ринку праці, $є$ потужним освітнім ресурсом. 


\section{СПИСОК ВИКОРИСТАНИХ ДЖЕРЕЛ}

1. Абдрахманова О. Роль переводческой ошибки в обучении переводу // Вестник Челябинского гос. ун-та. - 2014. - № 6. Филология. Искусствоведение. Вып. 88. - С. 6-9.

2. Асоціація перекладачів України - [Електронний ресурс]. - Режим доступу: http://www.uta.org.ua/translation_standards

3. Іншомовний дискурс: складові, проблеми вивчення та навчання. Кол. наук. дослідження. / За ред. Панченко О.І., док. філ. наук, проф., зав. кафедри перекладу ДНУ ім. Олеся Гончара - [Електронний ресурс]. - Режим доступу: http://lingvodnu.com.ua/downloads/2016_9.pdf

4. Общие принципы организации обучения переводу - [Електронний pecypc].

Режим доступу: http://studbooks.net/1026687/literatura/obschie_printsipy_organizatsii_obucheniya

5. Підручна 3. Психолого-педагогічні чинники формування професійної комунікативної компетентності майбутніх перекладачів у процесі фахової підготовки // Вісник Прикарпатського нац. університету ім. В. Стефаника: (педагогіка). - Івано-Франківськ, 2008. - Вип. XXVI. - С. 122 - 127.

6. Поворознюк Р. Теоретичні моделі перекладацької компетенції в аспекті відтворення медичного дискурсу / Науковий вісник Міжнародного гуманітарного університету. Сер.: Філологія, 2015. - № 14. - С. 245-249.

7. Рудіна М. Сучасні аспекти формування іншомовної комунікативної компетентності та навичок перекладу у студентів-філологів. Фаховий та художній переклад: теорія, методологія, практика: Мат. IX Міжнар. наук.практ. конф. (Київ, 15-16 квітня) - К.: Аграр Медіа Груп, 2016 - С. 335 - 340.

8. Рудіна М. Феномен перекладу в просторі професійного педагогічного дискурсу. Кременецькі компаративні студії: [Наук. часопис / Ред.: Чик Д., Пасічнік О.]. - Хмельницький: Цюпак А., 2015. - вип. V. - Т. 2. - С. 70 - 81.

9. Сафонова В. Коммуникативная компетенция: современные подходы к многоуровневому описанию в методических целях // О чем спорят в языковой педагогике. - М.: 2004. - 236 с. 
10. Селіванова О. Сучасна лінгвістика: напрями та проблеми / О. Селіванова. - Полтава: Довкілля-К, 2008. - 712 с. - С. 672.

11. Терминологический словарь-справочник / Отд. языкознания; Отв. редактор канд. филол. наук Раренко М.Б. - М., 2010. - 260 с.

12. Тренди в освіті 2017 року. - [Електронний ресурс]. - Режим доступу: https://www.eduget.com/news/golovni_trendi_v_osviti

13. Тренди освітніх технологій 2015 року. - [Електронний ресурс]. Режим доступу: http://www.inc.com/aaron-skonnard/5-top-trends-in-educationtechnology-2015.

14. Хомський Р. Язык и мышление: Пер. с англ. - М.: Мысль, 1972. - 352 с.

15. Чередниченко О. Складові професійної компетенції письмового та усного перекладача / Вісник Київського нац. ун-ту імені Тараса Шевченка. Іноземна філологія, 2007. - № 41. - С. 25-27.

16. Штанов A. Некоторые подходы к проблеме преподавания практического курса перевода в вузе // Филологические науки в МГИМО: Сб. науч. трудов / МГИМО(У) МИД России; Отв. ред. Л. Г. Кашкуревич. - М.: МГИМО, 2002. - С. 100-118.

17. Britell J.K. Competency and Excellence // Munimum Competency Achievement Testing/ Taeger R.M.\& Tittle C.K. (eds.) - Berekley, 1980 - P.23-29.

18. Durieux C. Fondement didactique de la traduction technique. La maison du dictionnaire, Paris, 2010.

19. Hymes D. Communicative Competence // Sociolinguistics Selected Readings / Ed. by J. B. Pride, J. Holmes. - London, 1972. - S. 269.

20. John Searle and his Critics, Ernest Lepore and Robert van Gulick (eds), Oxford/Cambridge, Mass.: Blackwell, 1991.

21. Kiraly D. Pathways to translation: Pedagogy and Process. Kent State University Press, Kent, Ohio,1995.

22. Murray R., Caulier-Grice J., Mulgan G. The Open Book of Social Innovation. - [Електронний pecypc]. - Режим доступу: https://www.nesta.org.uk/sites/default/files/the_open_book_of_social_innovation. 


\section{REFERENCES}

1. Abdrakhmanova O. Rol' perevodcheskoi oshybki v obychenii perevody [The role of translation mistakes in studying translation] // Vestnik Chelyabinskogo gos. Un-ta. - 2014. - № 6. Filologiya. Iskustvovedenie. Vyp. 88. - S. 6-9. [in Russian]

2. Asotsiatsiya perekladachiv Ukrainy [Association of translators of Ukraine] [Elektronnyi resyrs]. - Rezhym dostupu: http://www.uta.org.ua/translation_standards [in Ukrainian]

3. Inshomovnyi dyskurs: skladovi, problemy vyvchennya ta navchannya. [Foreign discourse: components, problems of learning and teaching] Kol. nauk. doslidzhennya. / Za red. Panchenko O.I., dok. fil. nauk, prof., zav. kafedry pereklady DNU im. Olesya Honchara [Elektronnyi resyrs]. - Rezhym dostupu: http://lingvodnu.com.ua/downloads/2016_9.pdf [in Ukrainian]

4. Obschie printsipy organizatsii obucheniya perevodu - [Common principles of organization of teaching translation] [Elektronnyi resyrs]. - Rezhym dostupu: http://studbooks.net/1026687/literatura/obschie_printsipy_organizatsii_obucheniya [in Russian]

5. Pidruchna Z. Psyhologo-pedagogichni chynnyky formuvannya profesiinoi komunikatyvnoi kompetentnosti maibutnih perekladachiv $\mathrm{u}$ protsesi fahovoi pidgotovku [Psycological and pedagogical factors of formation professional communicative competence of the future translators in the process of special preparation] // Visnyk Prykarpats'kogo national'nogo universytety im. V. Stefanika: (seriya: pedegogika). - Ivano-Frankivs'k, Vyp. XXVI. - S. 122 - 127. [in Ukrainian]

6. Povoroznyik R. Teoretychni modeli perecladatskoi kompetentsii $\mathrm{v}$ aspekti vidtvorennya medychnogo dyskursy [Theoretical models of translation competence in the aspect of rendering medical discourse] / Naukovyi visnyk Mizhnarodnogo gumanitarnogo universytety. Ser.: Filologiya, 2015. - № 14. - S. 245-249. [in Ukrainian]

7. Rudina M. Sychasni aspekty formuvannya inshomovnoi komunikatyvnoi kompetentnosti ta navychok pereklady u studentiv-filologiv. [Modern aspects of formation of communicative competence and translation skills of students of 
philology] Fahovyi ta hudozhniy pereklad: teoriya, metodologiya, praktyka: Mat. IX Mizhnar. nauk.-prakt. konf. (Kyiv, 15 - 16 kvitnya 2016 r.), - K.: Agrar Media Grup, 2016 - S. 335 - 340. [in Ukrainian]

8. Rudina M. Fenomen pereklady $\mathrm{v}$ prostori profesijnogo pedegogichnogo dyskursy. [Phenomenon of translation as a component of professional pedagogical discourse] Kremenetsky komparatyvni stydii: [Nauk. chsopys / Red.: Chyk D., Pasichnik O.]. - Khmelnitsky: Tsypak A., 2015, - vyp. V. - T 2. - S. 70 - 81. [in Ukrainian]

9. Safonova V. Kommunikativnaya competentsiya: sovremennye podhody $\mathrm{k}$ mnogoyrovnevomy opisanijy $\mathrm{v}$ metodicheskih tselyah [Communicative competence: modern approaches to multi-level description in methodical aims] // $\mathrm{O}$ chem sporiat $\mathrm{v}$ yazykovoi pedagogike. - M.: 2004. - 236 s. [in Russian]

10. Selivanova O. Sychasna lingvistyka: napryamy ta problemy [Modern linguistics: areas and problems] / O. Selivanova. - Poltava: Dovkillya - K, 2008. 712 s. - S.672 [in Ukrainian]

11. Terminologicheskiy slovar'-spravochnik [Terminology reference dictionary] / Otd. Yazykoznaniya: Otv. redaktor kand. filol. nauk Rarenko M.B. - M., 2010. 260 s. [in Russian]

12. Trendy v osviti 2017 roky. [Trends in education in 2017] - [Elektronnyi resyrs]. - Rezhym dostupu: https://www.eduget.com/news/golovni_trendi_v_osviti [in Ukrainian]

13. Trendy osvitnikh tehnologij 2015 roku. [Trends of educational technologies in 2015] - [Elektronnyi resyrs]. - Rezhym dostupu: http://www.inc.com/aaronskonnard/5-top-trends-in-education-technology [in Ukrainian]

14. Khomsky R. Yazyk I myshlenie: Per.s angl. [Language and Mentality: translation from English] - M.: Mysl”, 1972. - 352 s. [in Russian]

15. Cherednichenko O. Skladovi profesijnoi kompetentsii pys'movogo ta usnogo perekladacha [Components of professional written and oral translation competence of the translator] / Visnyk Kyivs'kogo natsional'nogo universytety imeni Tarasa Shevchenka. Inozemna filologiya, 2007. - №41. - S. 25-27. [in Ukrainian] 
16. Shtanov A. Nekotorye podhody $\mathrm{k}$ probleme prepodavaniya prakticheskogo kyrsa perevoda $\mathrm{v}$ vyze [Some approaches to the problem of teaching practical course of translation in higher educational establishment] // Filologicheskie nauki v MGIMO: Sb. nauch. trudov / MGIMO(U) MID Rossii; Otv. Red. L. G. Kashkurevich. - M.: MGIMO, 2002. - S. 100-118. [in Russian]

17. Britell J.K. Competency and Excellence // Munimum Competency Achievement Testing/ Taeger R.M.\& Tittle C.K. (eds.) - Berekley, 1980. - P.23-29.

18. Durieux C. Fondement didactique de la traduction technique. La maison du dictionnaire, Paris, 2010.

19. Hymes D. Communicative Competence // Sociolinguistics Selected Readings / Ed. by J. B. Pride, J. Holmes. - London, 1972. - S. 269.

20. John Searle and his Critics, Ernest Lepore and Robert van Gulick (eds), Oxford/Cambridge, Mass.: Blackwell, 1991.

21. Kiraly D. Pathways to translation: Pedagogy and Process. Kent State University Press, Kent, Ohio, 1995.

22. Murray R., Caulier-Grice J., Mulgan G. The Open Book of Social Innovation. - [Elektronnyi resyrs]. $\quad-\quad$ Rezhym dostupu: https://www.nesta.org.uk/sites/default/files/the_open_book_of_social_innovation. 